\title{
New record of Dumontia contorta and $D$. alaskana (Dumontiaceae, Gigartinales) in Korea
}

\author{
Pil Joon Kang, Jae Woo An and Ki Wan Nam *
}

\begin{abstract}
During a survey of marine algal flora, two gigartinalean species were collected from Pohang and Youngdeok located on the eastern coast of Korea. They share the generic morphological features of Dumontia. One is characterized by cylindrical to complanate thallus with multi- and uniaxial structure, somewhat inflated and contorted branches, and hollow medulla and cortex consisting of progressively smaller cells outwards. The other shows basically the same features as the former species but was smaller in size, as having $4-7 \mathrm{~cm}$ in thallus length and 1-2 $\mathrm{mm}$ in branch width rather than 15 and 2-5 $\mathrm{mm}$. Both species are distinguished from each other only by these morphometric features. However, it is supported by molecular analysis that both species are genetically distinct. In a phylogenetic tree based on internal transcribed spacer sequence, the two species nest in the same clade as Dumontia contorta and D. alaskana, respectively. The genetic distance between both sequences within the clade was calculated as $0.0-0.2 \%$, considered to be intra-specific for Dumontia. Based on the morphological and molecular analyses, the two Korean species are identified as D. contorta and D. alaskana described originally from Netherlands and Alaska, respectively. This is the first record of the two Dumontia species in Korea.
\end{abstract}

Keywords: Dumontia contorta, D. alaskana, Marine algae, Gigartinalean species, First record, Korea

\section{Background}

Gigartinales F. Schmitz is a large red algal order in which 38 families are currently accepted worldwide (Guiry and Guiry 2018). This order has an anatomical complex structure within Rhodophyta (Kraft and Robins 1985 ) and is characterized by vegetative and reproductive features, such as pit plugs without cap layers, auxiliary cells produced prior to fertilization, and transfer of zygote or zygote-derived nuclei from the carpogonium via an external connection (Kraft and Robins 1985).

One of the gigartinalean algae, Dumontia J.V. Lamouroux, is a common marine red algal genus with broad distribution in cool temperate waters of the Northern Hemisphere including Korea, Japan, USSR, Alaska, and the North Atlantic (eastern Canada and USA, Iceland, and Europe) (Guiry and Guiry 2018; Lindstrom 1988; Wilce and Davis 1984). This genus was established by Lamouroux (1813) to include four species. Of these,

\footnotetext{
* Correspondence: kwnam@pknu.ac.kr

Department of Marine Biology, Pukyong National University, Busan 48513, South Korea
}

however, only D. contorta (S.G. Gmelin) Ruprecht has been retained in the genus as lectotype species, while the remaining species have been transferred to other genera (Guiry and Guiry 2018; Setchell 1914). It belongs to Dumontiaceae Bory, in which all species have the carpogonial and auxiliary cell branches of a separate system (nonprocarpic) and carogonium fusing with another cell of the carpogonial branch before the formation of connecting filaments (Mitchell 1966). In addition, species of the genus Dumontia shares the following features: cylindrical to complanate thallus with multi- and uniaxial structure, branched or unbranched axis, filamentous and mostly hollow medulla, cortex of progressively smaller and nearly spherical cells, superficial spermatangia cut off by oblique walls, immersed cystocarps, and isomorphic tetrasporophyte with large and cruciate tetrasporangia originated from the inner cortical cells (Abbott 1979; Guiry and Guiry 2018; Lindstrom 1985, 1988; Tai et al. 2001; Wilce and Davis 1984).

Six species are currently placed under the genus Dumontia (Guiry and Guiry 2018). Of these, only Dumontia simplex A.D. Cotton (1906), which was originally described 
from Korea, has been reported in the marine algal flora of Korea (Kim et al. 2013; Lee and Kang 1986, 2002). During a survey of marine algal flora, two gigartinalean algae were collected from Pohang and Youngdeok on the eastern coast of Korea. These two species were identified based on morphological and molecular analyses and are newly recorded in Korea in the present study.

\section{Methods}

Specimens for this study were collected from Pohang and Youngdeok located on the eastern coast of Korea. Taxonomic data were obtained from fresh, liquid-preserved, and herbarium specimens. Liquid-preserved material was stored in a $10 \%$ solution of formalin/seawater. The blades dissected from the cleared materials were hand sectioned, transferred to a slide with distilled water, and mounted in pure glycerin. Measurements are given as width and length. For permanent slides, the glycerin was exchanged with $10-20 \%$ corn syrup.

Total genomic DNA was extracted from silica-gel-preserved samples using the DNeasy Plant Mini Kit (Qiagen, Hilden, Germany) according to the manufacturer's protocol. Before extraction, dried material was crushed with liquid nitrogen using a mortar and pestle. Extracted DNA was used for amplification of internal transcribed spacer (ITS) regions. PCR amplifications were performed in a TaKaRa PCR Thermal Cycler Dice (TaKaRa Bio Inc., Otsu, Japan). ITS regions were PCR amplified as a single fragment with the primers ITSP1 (5' GGAAGGAGAAGTCGTAACAAGG 3') and G4 (5' CTTTTCCTCCGCTTATTGATATG 3') (Harper and Saunders 2001) or as two overlapping fragments with the primers ITSP1 and ITSR1 (5' TTCAAAGAT TCGATGATTCAC 3') and P5 (5' GCATCGATGAAGA ACGCAG 3') and G4 (Harper and Saunders 2001). The PCR products were moved to Macrogen Sequencing Service for sequencing (Macrogen, Seoul, Korea). The PCR primers were also used for sequencing.

Sequences for the ITS region were aligned using BioEdit (Hall 1999). Phylogenetic analyses were performed using neighbor-joining, maximum-likelihood, and maximum parsimony methods. Bootstrap values were calculated with 1000 replications. ITS sequences of other species were obtained from GenBank. Phyllophora crispa (Hudson) P.S. Dixon was used as an out-group.

\section{Results and discussion}

Dumontia contorta (S.G. Gmelin) Ruprecht 1850: 103.

Type locality: Ad litus Scheuelingense prope Hagam comium e mari reiectum Cel. Pallas (Gmelin 1768).

Korean name: Dong-hae-mi-kkeul-pul nom. nov. (신 칭 : 동해미끌풀).

Specimens examined: NIBRRD0000001652, MGARBb00 0750 (Igari, Pohang: 04.xii.2015).
Habitat: Epilithic near the intertidal.

Morphology: Thalli up to $15 \mathrm{~cm}$ high, erect, terete near base but becoming flattened, somewhat inflated and contorted, hollow, bright to dark red in color, lubricous in texture, attached to substratum by discoid holdfast (Fig. 1a); main axes multiaxial in lower part but uniaxial near apex, issuing irregularly lateral uniaxial branches with wide axils, 2-5 $\mathrm{mm}$ in width; branches markedly attenuate, slightly constricted at base, with tapering apex (Fig. 1b); cortex compact, several cell layers thick, consisting of progressively smaller, round to elliptical cells of $2-3 \times 4-5 \mu \mathrm{m}$ in size (Fig. 1c); medullary cells large, ovoid to elliptical, intermixed with filaments of $50-150 \mu \mathrm{m}$ in diam (Fig. 1d-f). Tetrasporangial and sexual plants were not observed in the present study.

Dumontia alaskana V. Tai, S.C. Lindstrom \& G.W. Saunders 2001: 194.

Type locality: Shaman Island, Alaska, USA (Tai et al. 2001).

Korean name: Buk-bang-mi-kkeul-pul nom. nov. (신 칭: 북방미끌풀).

Specimens examined: NIBRRD0000001654, MGARBb 000751 (Daejin, Youngdeok: 04.xii.2016).

Habitat: Epilithic near the intertidal.

Morphology: Thalli 4-7 cm high, erect, terete, hollow, dark red in color, cartilagenous or somewhat lubricous in texture, attached to substratum by discoid holdfast (Fig. 2a); main axes issuing irregularly lateral branches with wide axils, $1-2 \mathrm{~mm}$ in width; mature structure multiaxial; cortex compact, several cell layers thick, consisting of small, round to elliptical cells of $2-5 \times 4-7 \mu \mathrm{m}$ in size (Fig. 2c); medulla of large cells, intermixed with filaments of $70-80 \mu \mathrm{m}$ in diam (Fig. 2b); tetrasporangia produced from inner cortical cells (Fig. 2e), with cruciate division, ovoid to elliptical, $15-20 \times 26-50 \mu \mathrm{m}$ in size (Fig. $2 \mathrm{~d}$ ). Sexual plants were not observed in the present study.

Lectotype species of the genus Dumontia is D. incrassata (O.F. Müller) J.V. Lamouroux (Guiry and Guiry 2018). However, the correct name currently accepted for the type species is D. contorta (S.G. Gmelin) Ruprecht lectotypified with Gmelin's original illustration (Gmelin 1768, pl. XXII, Fig. 1) (Abbott 1979). According to Gmelin's original descriptions based on the specimen collected from Scheveningen, Netherlands, thalli of $D$. contorta appear to be flat, subundulate, and suncontorted. In particular, its thalli often become inflated, distorted, and twisted when old, in sheltered areas (Irvine 1983). These gross morphological features are found in the Korean alga collected from Igari, Pohang. However, the thallus length and branch diameter of the Korean specimens were not as large as those of $D$. contorta reported by the previous authors (Rosenvinge 1917; Whelden 1928; Tai et al. 2001, see 195p.).

Recently, D. alaskana was described from North Pacific isolate (Alaska), which is genetically distinct from 

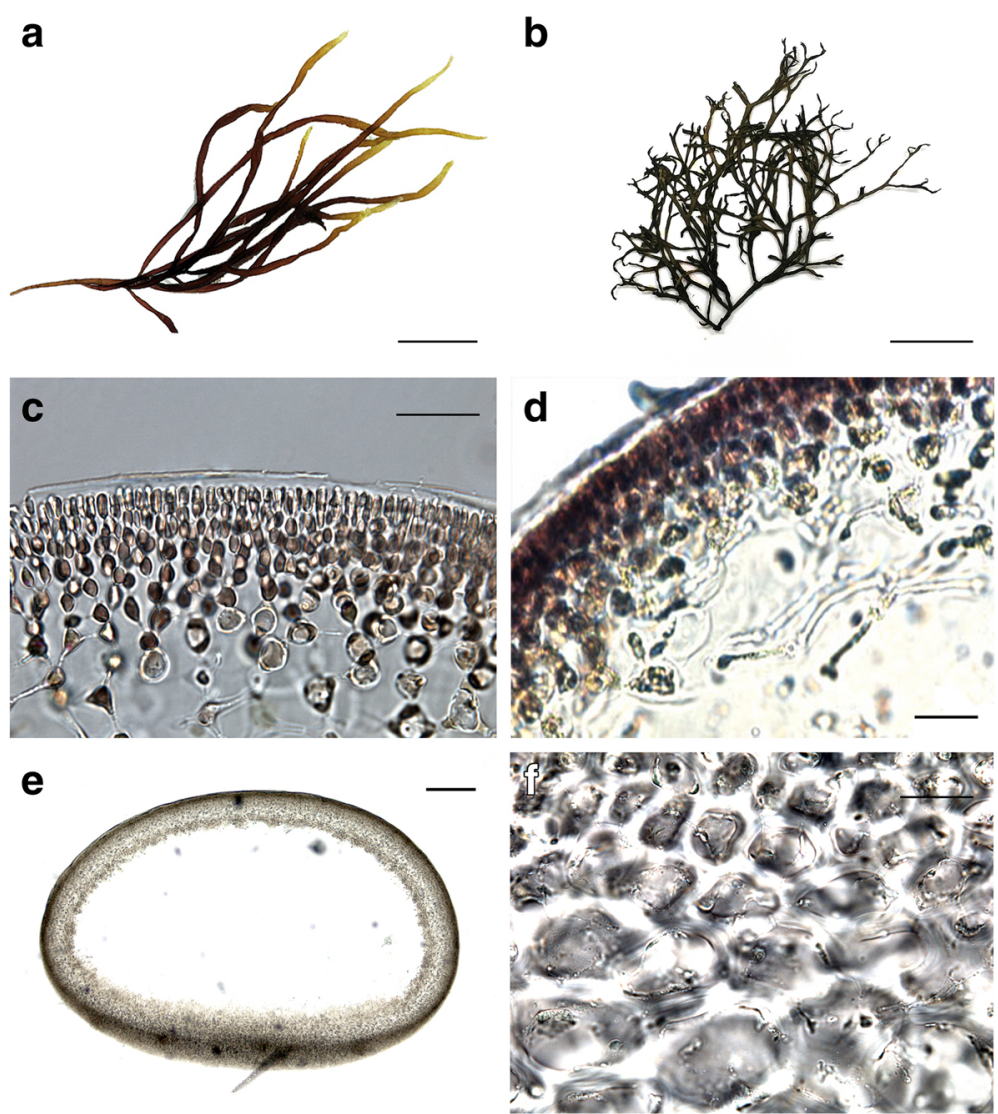

Fig. 1 Dumontia contorta (S.G. Gmelin) Ruprecht. a Vegetative plants. b Herbarium specimen. c Cortical cell layers. d Medulla intermixed with filaments. e Transverse section of flattened branch with hollow medulla. $\mathbf{f}$ Multiaxial medulla of round to elliptical cells in the lower part of main axis. Bars in a $2 \mathrm{~cm}, \mathbf{b} 3 \mathrm{~cm}, \mathbf{c} 20 \mu \mathrm{m}, \mathbf{d} 20 \mu \mathrm{m}, \mathbf{e} 200 \mu \mathrm{m}$, and f $200 \mu \mathrm{m}$

a

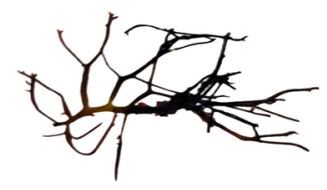

b
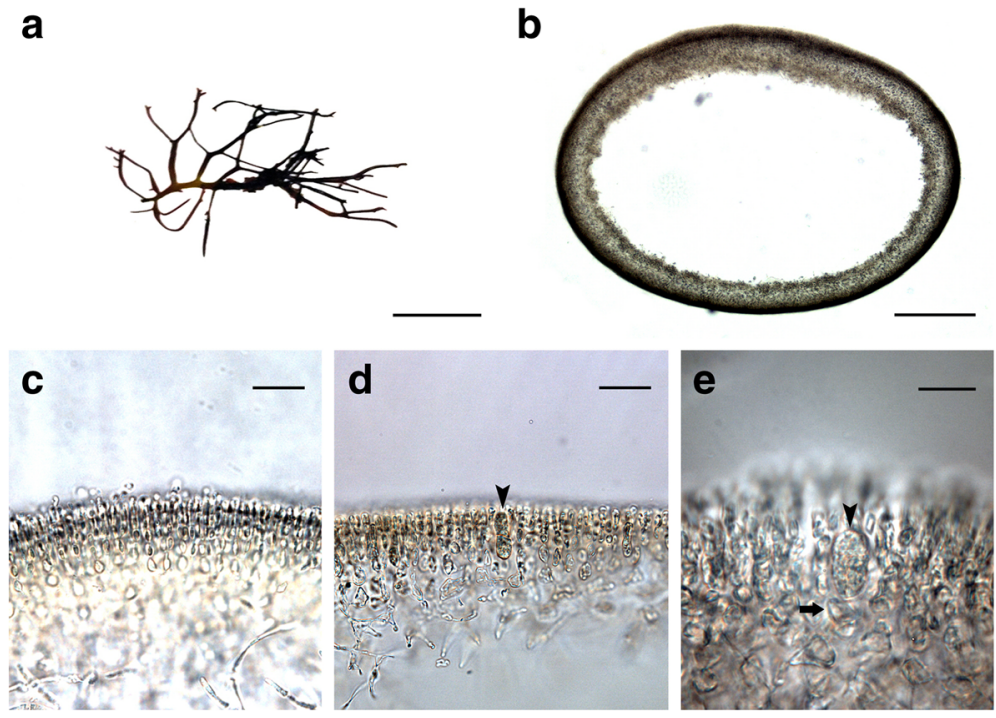

Fig. 2 Dumontia alaskana V. Tai, S.C. Lindstrom \& G.W. Saunders. a Herbarium specimen. b Transverse section of the branch with hollow medulla. c Cortex consisting of progressively smaller cells outwards. d Cortical cell layers with tetrasporangium (arrowhead). e Tetrasporangium (arrowhead) produced from the inner cortical cell (arrow). Bars in a $2 \mathrm{~cm}, \mathbf{b} 200 \mu \mathrm{m}, \mathbf{c} 20 \mu \mathrm{m}, \mathbf{d} 30 \mu \mathrm{m}$, and e $20 \mu \mathrm{m}$ 


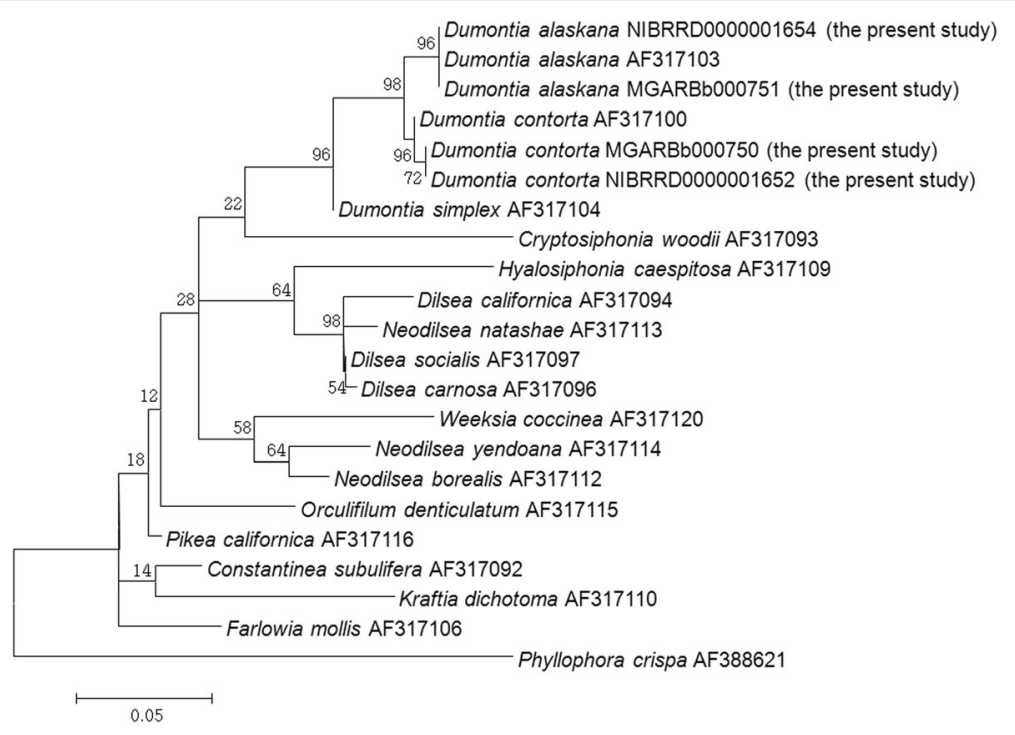

Fig. 3 Phylogenetic tree of species in Dumontiaceae obtained from maximum-likelihood method based on ITS sequences. Bootstrap proportion values (1000 replicates samples) are shown above branches. Scale bar $=0.05$ substitutions/site

North Atlantic populations of D. contorta (Tai et al. 2001). Morphological differences between both species are observed only in quantitative features, such as size of the thallus, carposporangia, and tetrasporangia (Tai et al. 2001). However, this species is currently accepted (Guiry and Guiry 2018). Similarly, the second Korean species, which was collected from Daejin, shares the same morphological features as D. alaskana, but differs from the species in their size. Its thallus length and branch diameter were smaller than those of D. alaskana (Lindstrom 1985; Tai et al. 2001). Tetrasporangia size was also smaller, as compared with that of D. alaskana described originally from Alaska (Tai et al. 2001). It does not appear to be genetically distinct from $D$. alaskana, even though the Korean alga shows different size in the vegetative and reproductive features. This is also supported by molecular analyses (Fig. 3).

According to Tai et al. (2001), D. alaskana has a smaller thallus but larger sporangia, as compared with D. contorta. This morphometric feature of the thallus between both species was also found in the Korean specimens collected during the present study, even though comparison of sporangia cannot be made. The Korean populations of both species seem to have remarkably smaller thallus than those from Alaska and the North Atlantic based on the present observation.

In a phylogenetic tree based on ITS sequence (Fig. 3), the Korean algal sequences nest in the same clade as those of D. contorta from Canada (the North Atlantic) and D. alaskana from Alaska (type locality), respectively. The genetic distance between both sequences within each clade was $0.0-0.2 \%$. According to $\mathrm{Hu}$ et al. (2009), the intra- and inter-specific divergence range for Dumontia are 0.0-0.2 and 9.6-18.4\%, respectively. In the present study, inter-specific distance was calculated as $0.4-14.2 \%$ in Dumontiaceae. This morphological and molecular evidence suggests that the two Korean gigartinalean algae should be identified as $D$. contorta and D. alaskana, respectively. This is the first record of the two Dumontia species in Korea.

\section{Conclusions}

Based on the morphological and molecular analyses, two gigartinalean species that were collected from Pohang and Youngdeok located on the eastern coast of Korea are identified as D. contorta and D. alaskana described originally from Netherlands (the North Atlantic) and Alaska, respectively. This is the first record of the two Dumontia species in Korea.

\section{Abbreviation}

ITS: Internal transcribed spacer

\section{Funding}

This work was supported by a grant from the National Institute of Biological Resources (NIBR) funded by the Ministry of Environment (MOE) of the Republic of Korea (NIBR201601204) and by the Marine Biotechnology Program of the Korea Institute of Marine Science and Technology Promotion (KIMST) funded by the Ministry of Oceans and Fisheries (MOF) (No. 20170431).

\section{Availability of data and materials}

All datasets analyzed during the current study are available from the corresponding author on reasonable request.

\section{Authors' contributions}

PJK and JWA conducted the research, analyzed the materials, and prepared the draft manuscript. KWN designed and directed the study and finalized the manuscript. All authors read and approved the final manuscript.

Ethics approval and consent to participate Not applicable. 


\section{Consent for publication}

Not applicable.

\section{Competing interests}

The authors declare that they have no competing interests.

\section{Publisher's Note}

Springer Nature remains neutral with regard to jurisdictional claims in published maps and institutional affiliations.

Received: 25 May 2018 Accepted: 12 July 2018

Published online: 12 October 2018

\section{References}

Abbott IA. Taxonomy and nomenclature of the type species of Dumontia Lamouroux (Rhodophyta). Taxon. 1979;28:563-6.

Cotton AD. Marine algae from Corea. Bull Misc Inf Roy Bot Gard Kew. 1906;1906: $336-73$.

Gmelin SG. Historia fucorum. St. Petersburg: Petropol; 1768.

Guiry MD, Guiry GM. AlgaeBase. Galway: World-wide electronic publication, National University of Ireland; 2018. http://www.algaebase.org. Accessed 15 May 2018

Hall TA. BioEdit: a user-friendly biological sequence alignment editor and analysis program for Windows 95/98/NT. Nucleic Acids Symp Ser. 1999;41:95-8.

Harper JT, Saunders GW. The application of sequences of the ribosomal cistron to the systematic and classification of the florideophyte red algae (Florideophyceae, Rhodophyta). Cah Biol. 2001;42:25-38.

Hu ZM, Guiry MD, Duan DL. Using the ribosomal internal transcribed spacer (ITS) as a complement marker for species identification of red macroalgae. Hydrobiologia. 2009;635:279-87.

Irvine LM. Seaweeds of the British Isles. Volume 1. Rhodophyta. Part 2A. Cryptonemiales (sensu stricto), Palmariales, Rhodymeniales. London: British Museum (Natural History); 1983.

Kim HS, Boo SM, Lee IK, Sohn CH. National list of species of Korea: marine algae. Seoul: Jeonghaengsa; 2013.

Kraft GT, Robins PA. Is the order Cryptonemiales (Rhodophyta) defensible? Phycologia. 1985;24:67-77.

Lamouroux JVF. Essai sur les genres de la famille des thalassiophytes non articulées. Ann Mus Hist Nat. 1813;20:21-47.

Lee IK, Kang JW. A check list of marine algae in Korea. Kor J Phycol. 1986;1:311-25.

Lee YP, Kang SYA. Catalogue of the seaweeds in Korea. Jeju: Jeju: National University Press; 2002

Lindstrom SC. A phylogenetic systematics study of the red algal family Dumontiaceae. PhD thesis. Vancouver: Univ. British Columbia; 1985.

Lindstrom SC. The Dumontieae, a resurrected tribe of red algae (Dumontiaceae, Rhodophyta). Phycologia. 1988;27:89-102.

Mitchell EA. The southern Australian genera of the Dumontiaceae (Rhodophyta). Nova Hedwigia. 1966;11:209-20.

Rosenvinge K. The marine algae of Denmark. Part II. Rhodophyceae. II (Cryptonemiales). København: Bianco Lunos; 1917.

Ruprecht FJ. Algae Ochotenses. St. Petersburg: Die ersten sicheren Nachrichten über die Tange des Ochotskischen Meeres; 1850.

Setchell WA. The Scinaia assemblage. Univ Calif Publ Bot. 1914;6:79-152.

Tai V, Lindstrom SC, Saunders GW. Phylogeny of the Dumontiaceae (Gigartinales, Rhodophyta) and associated families based on SSU rDNA and internal transcribed spacer sequence data. J Phycol. 2001;37:184-96.

Whelden RM. Observations of the red algae Dumontia filiformis. Maine Nat. 1928; 8:121-30.

Wilce RT, Davis AN. Development of Dumontia contorta (Dumontiaceae, Cryptonemiales) compared with that of other higher red algae. J Phycol. 1984;20:336-51.

\section{Ready to submit your research? Choose BMC and benefit from:}

- fast, convenient online submission

- thorough peer review by experienced researchers in your field

- rapid publication on acceptance

- support for research data, including large and complex data types

- gold Open Access which fosters wider collaboration and increased citations

- maximum visibility for your research: over $100 \mathrm{M}$ website views per year

At BMC, research is always in progress.

Learn more biomedcentral.com/submissions 